\title{
COI mtDNA barcoding and morphology for the description of a new species of ricinuleid of the genus Pseudocellus (Arachnida: Ricinulei: Ricinoididae) from El Triunfo Biosphere Reserve, Chiapas, Mexico
}

\author{
Alejandro VALDEZ-MONDRAGÓN ${ }^{\circledR} 1{ }^{* *}$ \& Mayra R. CORTEZ-ROLDÁN ${ }^{\circledR} 2$ \\ ${ }^{1}$ CONACYT Research Fellow. Laboratory of Arachnology (LATLAX), Laboratorio Regional de \\ Biodiversidad y Cultivo de Tejidos Vegetales (LBCTV), Instituto de Biología, Universidad Nacional \\ Autónoma de México (UNAM), sede Tlaxcala, Ex-Fábrica San Manuel, San Miguel Contla, \\ 90640 Santa Cruz Tlaxcala, Tlaxcala, Mexico. \\ ${ }^{1,2}$ Laboratory of Arachnology (LATLAX), Laboratorio Regional de Biodiversidad y Cultivo \\ de Tejidos Vegetales (LBCTV), Instituto de Biología, \\ Universidad Nacional Autónoma de México (UNAM), sede Tlaxcala, Mexico. \\ ${ }^{1}$ Colección Nacional de Arácnidos (CNAN), Departamento de Zoología, Instituto de Biología, \\ Universidad Nacional Autónoma de México (UNAM), Ciudad Universitaria, \\ Apartado Postal 04510, Coyoacán, Mexico City, Mexico. \\ ${ }^{2}$ Posgrado en Ciencias Biológicas (Maestría), Centro Tlaxcala de Biología de la Conducta (CTBC), \\ Universidad Autónoma de Tlaxcala (UATx), Carretera Federal Tlaxcala-Puebla, km 1.5, \\ C.P. 90062 , Tlaxcala, Tlaxcala, Mexico. \\ ${ }^{*}$ Corresponding author: lat_mactans@yahoo.com.mx \\ ${ }^{2}$ Email: roxio_cortez153b@hotmail.com \\ ${ }^{1}$ urn:lsid:zoobank.org:author:F043A1C7-2B83-40C9-A74E-82C92F00725A
${ }^{2}$ urn:Isid:zoobank.org:author:5FAA31AB-B5BC-47B6-BBA2-2DCC34B33C23
}

\begin{abstract}
A new species of epigean ricinuleid of the genus Pseudocellus Platnick, 1980 from El Triunfo Biosphere Reserve, Chiapas, Mexico is described. DNA barcoding utilizing mitochondrial cytochrome c oxidase subunit 1 (CO1) and morphology were used for species delimitation. Molecular analyses and species delimitation included four methods: 1) General Mixed Yule Coalescent model (GMYC), 2) Automatic Barcode Gap Discovery (ABGD), 3) Bayesian Poisson Tree Process (bPTP), and 4) Assemble Species by Automatic Partitioning (ASAP). All molecular methods and morphology were consistent in delimiting and recognizing the new species described herein. The average interspecific genetic distance ( $p$-distance) among analyzed species of Pseudocellus was $11.6 \%$. The species is described based on adult males and females: Pseudocellus giribeti sp. nov. This is the seventh species described from Chiapas, which holds the highest number of ricinuleids species for the country. The total number of described species of Pseudocellus from Mexico increases to 21, having the highest species diversity of known ricinuleids worldwide.
\end{abstract}

Keywords. Molecular markers, integrative taxonomy, species delimitation methods, Neotropic, Neoricinulei. 
Valdez-Mondragón A. \& Cortez-Roldán M.R. 2021. COI mtDNA barcoding and morphology for the description of a new species of ricinuleid of the genus Pseudocellus (Arachnida: Ricinulei: Ricinoididae) from El Triunfo Biosphere Reserve, Chiapas, Mexico. European Journal of Taxonomy 778: 1-25.

https://doi.org/10.5852/ejt.2021.778.1563

\section{Introduction}

Currently, Ricinulei Thorell, 1876 is the second least diverse order of Arachnida Cuvier, 1812, comprising 101 extant (including the new species herein described) and 22 fossil species. The order is composed by the Suborders Palaeoricinulei Selden, 1992 and Neoricinulei Selden, 1992, including extinct and living species, respectively (Selden 1992; Harvey 2003). Wunderlich $(2012,2015)$ modified the proposed classification such that all previously known species be placed in Suborder Posteriorricinulei Wunderlich, 2015, and the newly discovered fossil, Primoricinuleus pugio Wunderlich, 2015, was assigned to suborder Primoricinulei Wunderlich, 2015. Wunderlich (2017) proposed two new families of extinct ricinuleids, described in the Primoricinulei: Hirsutisomidae Wunderlich, 2017 and Monooculricinuleidae Wunderlich, 2017.

The Superfamily Ricinoidoidea Ewing, 1929 comprises three genera: Cryptocellus Weestwood, 1874 (New World), Pseudocellus Platnick, 1980 (New World) and Ricinoides Ewing, 1929 (western and central African countries); with 45, 37 and 16 species, respectively, described so far (Tuxen 1974; Naskrecki 2008; Penney et al. 2009; Valdez-Mondragón \& Francke 2011, 2013; Valdez-Mondragón et al. 2018, 2020; Valdez-Mondragón \& Juárez-Sánchez 2021; Botero-Trujillo et al. 2021a, 2021b). The species of the genus Pseudocellus are distributed mainly in North and Central America, with some species from Caribbean islands (Harvey 2003; Teruel \& Armas 2008; Armas \& Agreda 2016; Armas 2017; ValdezMondragón \& Francke 2011, 2013; Valdez-Mondragón et al. 2018, 2020; Valdez-Mondragón \& JuárezSánchez 2021).

Mexico holds first place in the number of known ricinuleid species worldwide, with 20 described species (not including the new species described herein), all belong to the genus Pseudocellus. The Mexican species are typically found in the soil in lowland tropical rainforests, inside the leaf litter, in underlying soil layers, and under big rocks and rotten logs (Platnick 2002; Harvey 2003; Valdez-Mondragón \& Francke 2011, 2013; Valdez-Mondragón et al. 2018, 2020; Valdez-Mondragón \& Juárez-Sánchez 2021). Some species have even been found in a temperate forest, in pine-oak forest, in an extensive karstic zone at $2169 \mathrm{~m}$ elev. (e.g., Pseudocellus jarocho Valdez-Mondragón \& Francke, 2011). Most of the described species from Mexico are epigean, although some species are found frequently in caves, having true troglobites with distinct troglomorphisms. Mexico hosts the largest number of known troglobitic ricinuleids so far, with eight species: Pseudocellus bolivari (Gertsch, 1971), P. boneti (Bolívar y Pieltain, 1942), P. monjarazi Valdez-Mondragón \& Francke, 2013, P. osorioi (Bolívar y Pieltain, 1946), P. oztotl Valdez-Mondragón \& Francke, 2011, P. platnicki Valdez-Mondragón \& Francke, 2011, P. reddelli (Gertsch, 1971) and P. sbordonii (Brignoli, 1974). Among the species discovered in the last ten years from Mexico, seven are epigean and three are troglobitic (Valdez-Mondragón \& Francke 2011, 2013; Valdez-Mondragón et al. 2018, 2020; Valdez-Mondragón \& Juárez-Sánchez 2021).

In modern taxonomy, it is generally accepted that the use of multiple lines of evidence, such as morphology, ecology, reproduction, and biogeography (integrative taxonomy), are more effective in the diagnosis, delimitation, and even the description of species (Valdez-Mondragón 2020). Several recently developed molecular delimitation methods have highlighted the extensive inconsistency in classical morphological taxonomy used on different groups of arachnids (Hamilton et al. 2011, 2014, 2016; Ortiz \& Francke 2016; Tahami et al. 2017; Cruz-López et al. 2019; Valdez-Mondragón et al. 2019; Navarro-Rodríguez \& Valdez-Mondragón 2020). However, the molecular delimitation methods using mitochondrial markers 
have never been used in ricinuleids so far. Molecular methods have provided a new way to resolve species delimitation problems by using the infraspecific genealogical information in DNA markers which provides objective implementation of modern species concepts (e.g., biological, phylogenetic, genotypic cluster) (Valdez-Mondragón et al. 2019). For species delimitation research, the appropriate way is to analyze the data with a wide variety of methods and different lines of evidence to delimit lineages, which must be consistent across the results, to understand the behavior of the molecular species delimitation methods and thus contribute to integrative taxonomy (Carstens et al. 2013; Luo et al., 2018).

In this study we describe a new epigean species of the genus Pseudocellus from a cloud forest of the state of Chiapas, Mexico, based on morphological evidence and DNA barcoding (CO1). This study currently represents the first one using different molecular species delimitation methods including morphology with ricinuleids.

\section{Material and methods}

\section{Biological material}

The collected specimens were preserved in $80 \%$ ethanol. The type material are deposited in the Invertebrate Zoology collection in the Museum of Comparative Zoology, Harvard University, USA (MCZ), and in the Colección Nacional de Arácnidos (CNAN), Institute of Biology, Universidad Nacional Autónoma de México (IBUNAM), Mexico City. The descriptions and observations of the specimens were done using a Zeiss Discovery V8 stereo microscope. A Zeiss Axiocam 506 color camera attached to a Zeiss AXIO Zoom V16 stereo microscope was used to photograph the different structures of specimens. All measurements are in millimeters ( $\mathrm{mm}$ ). Male copulatory apparatus and female spermathecae were dissected previous to observation. Photography was conducted with specimens and structures submerged in commercial gel alcohol (to hold them in the appropriate position), and the preparation completely covered with $80 \%$ ethanol. Digital images were edited in Adobe Photoshop CS6. The distribution map was produced using QGIS 3.18.3 "Zürich" (QGIS.org). The terminology used for leg segments follows Gertsch (1971), whereas for the copulatory structures we follow Pittard \& Mitchell (1972) and ValdezMondragón et al. $(2018,2020)$. The length/diameter (1/d) ratio of femur II of males was calculated in prolateral view. The abbreviations below are used for some copulatory structures following BoteroTrujillo \& Valdez-Mondragón (2016).

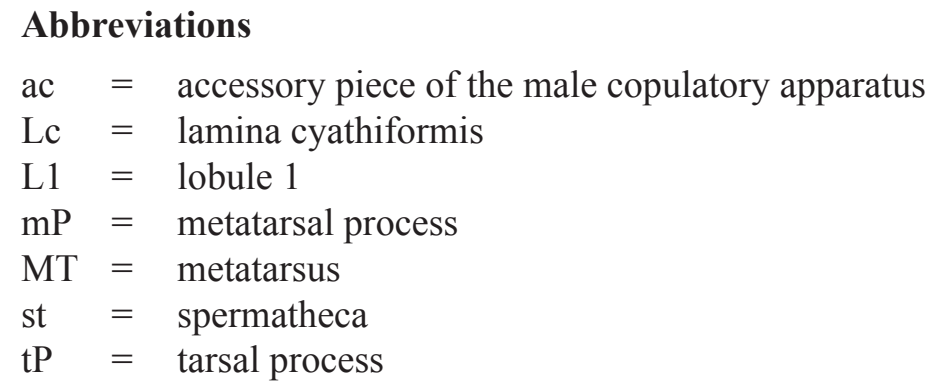

\section{Taxon sampling}

The molecular analyses presented here are based on a total of 30 samples of 12 species, including the new species described herein and one single outgroup: Ricinoides aff. feae (Hansen, 1921) used only to root the trees. The ingroup includes 29 samples of Pseudocellus. The samples used in the molecular analyses are listed in Table 1. All the CO1 sequences were downloaded from GenBank (Table 1). The total process of DNA extraction, sequencing and sequence-editing was described by Murienne et al. (2013) and Fernández \& Giribet (2015). DNA voucher numbers correspond to the database of the Museum of Comparative Zoology (MCZ) (mczbase.mcz.harvard.edu), Harvard University (Table 1). 
Table 1. Samples of Pseudocellus Platnick, 1980 used for molecular analyses, DNA voucher numbers, localities, and GenBank accession numbers for CO1.

\begin{tabular}{|c|c|c|c|}
\hline Species & $\begin{array}{c}\text { DNA } \\
\text { voucher } \\
\text { MCZ }\end{array}$ & Locality & $\begin{array}{c}\text { GenBank } \\
\text { accession } \\
\text { number }\end{array}$ \\
\hline Ricinoides aff. feae & - & Guinea-Bissau & KR180469.1 \\
\hline P. boneti & 130046.2 & Cueva de Michapa, Town of Michapa, Morelos, Mex. & KR180451.1 \\
\hline P. boneti & 130046 & Cueva de Michapa, Town of Michapa, Morelos, Mex. & KR180446.1 \\
\hline P. gertschi & 130036 & Estación Biol. UNAM, Los Tuxlas, Veracruz, Mex. & KR180436.1 \\
\hline P. giribeti & 80001.2 & Res. Bios. El Triunfo, Camp. El Quetzal, Chis., Mex. & KR180459.1 \\
\hline P. giribeti & 80001.1 & Res. Bios. El Triunfo, Camp. El Quetzal, Chis., Mex. & KR180458.1 \\
\hline P. giribeti & 79966.1 & Res. Bios. El Triunfo, Camp. El Quetzal, Chis., Mex. & KR180457.1 \\
\hline P. giribeti & 79891.5 & 4 km SE Custepec, Chis., Mex. & KR180456.1 \\
\hline P. giribeti & 79891.4 & 4 km SE Custepec, Chis., Mex. & KR180455.1 \\
\hline P. giribeti & 79891.3 & 4 km SE Custepec, Chis., Mex. & KR180454.1 \\
\hline P. giribeti & 79891.2 & 4 km SE Custepec, Chis., Mex. & KR180453.1 \\
\hline P. giribeti & 79891.1 & 4 km SE Custepec, Chis., Mex. & KR180452.1 \\
\hline P. giribeti & 79799.4 & 3 km SE Custepec, Chis. Mex. & KR180450.1 \\
\hline P. giribeti & 80243 & Res. Bios. El Triunfo, Camp. El Quetzal, Chis., Mex. & KR180435.1 \\
\hline P. giribeti & 80112 & Res. Bios. El Triunfo, Camp. El Quetzal, Chis., Mex. & KR180434.1 \\
\hline P. giribeti & 80091 & Res. Bios. El Triunfo, Camp. El Quetzal, Chis., Mex. & KR180433.1 \\
\hline P. giribeti & 79891 & 4 km SE Custepec, Chis., Mex. & KR180426.1 \\
\hline P. giribeti & 79799 & 3 km SE Custepec, Chis., Mex. & JX951411.1 \\
\hline P. monjarazi & 136272 & Cueva de San Francisco, La Trinitaria, Chis., Mex. & KR180447.1 \\
\hline P. sbordonii & 136270 & Cueva de las Abejas, San Fernando, Chis., Mex. & KR180448.1 \\
\hline Pseudocellus sp. & 99190 & 5 km SE Antigua, Honduras & KR180449.1 \\
\hline Pseudocellus sp. & 89406 & 5 km SE Antigua, Guatemala & KR180445.1 \\
\hline Pseudocellus sp. & 83165 & Cerro Carmona, Finca El Pilar, Guatemala & KR180444.1 \\
\hline Pseudocellus sp. & 99193 & Parque Nacional La Muralla, Honduras & KR180443.1 \\
\hline Pseudocellus sp. & 99283 & Refugio El Quetzal, Guatemala & KR180442.1 \\
\hline Pseudocellus sp. & 89422 & 4 km S Volcán, Atitlán, Guatemala & KR180441.1 \\
\hline Pseudocellus sp. & 89548 & $5 \mathrm{~km}$ NW Morales, Guatemala & KR180440.1 \\
\hline Pseudocellus sp. & 89536 & $5 \mathrm{~km}$ NW Morales, Guatemala & KR180439.1 \\
\hline Pseudocellus sp. & 98424 & 13 km E Nuevo Ocotepeque, Honduras & KR180437.1 \\
\hline Pseudocellus sp. & 98418 & Parque Nacional La Muralla, Honduras & KR180438.1 \\
\hline
\end{tabular}




\section{DNA sequence alignment and editing}

Sequences were aligned using the default Gap opening penalty of 1.53 in MAFFT (Multiple sequences Alignment based on Fast Fourier Transform), ver. 7 (Katoh \& Toh 2008), available online, using the following alignment strategy: Auto (FFT-NS-2, FFTNS-i or L-INS-i; depending on data size). Inspection and editing of sequences and alignments were done using GENEIOUS ver. 10.2.6. The matrix obtained from the multiple sequence alignments was then used in the different analyses.

\section{Molecular analyses and species delimitation}

For molecular analyses and species delimitation with molecular data, we carried out a previous tree of genetic $(p)$ distances under neighbor joining (NJ) using MEGA ver. 7.0 (Tamura et al. 2007), in order to make a first exploration of morphospecies similarity. Four molecular methods for species delimitation were used: 1) General Mixed Yule Coalescent model (GMYC) (Pons et al. 2006) using the GMYC web server (https://species.h-its.org/gmyc/); 2) automatic barcode gap discovery (ABGD) online version (Puillandre et al. 2012) using both uncorrected and K2P distance matrices; 3) bayesian Poisson Tree Process (bPTP) (Zhang et al. 2013; Kapli et al. 2017) using the web server (https://species.h-its.org/ptp/); and 4) Assemble Species by Automatic Partitioning (ASAP) online version (Puillandre et al. 2020) using Kimura (K80) distance matrices.

\section{Starting trees under Maximum Likelihood (ML)}

The approaches for DNA barcoding tree-based delimitation explicitly use the phylogenetic and cladistic species concepts. A starting tree was inputted with ML using MEGA ver. 7.0. The analysis recognizes a monophyletic cluster by searching differential intra- and interspecific branching patterns (Ortiz \& Francke 2016; Valdez-Mondragón 2020). The ML analysis was calculated with the following parameters: Number of replicates $=1000$, Bootstrap support values $=1000$ (significant values $\geq 50 \%$ ), Models of sequence evolution selected using jModelTest $=$ GTR, Rates among sites $=\mathrm{G}+\mathrm{I}$, No. of discrete Gamma Categories $=6$, Gaps Data Treatment $=$ Complete deletion, Select Codon Position $=1^{\text {st }}+2^{\text {nd }}$ and $3^{\text {rd }}$, ML Heuristic Method = Subtree-Pruning-Regrafting - Extensive (SPR level 5), Initial Tree of ML $=$ Make initial tree automatically (Default - NJ/BioNJ). The models of sequence evolution were selected using jModelTest ver. 2.1.10 with the Akaike information criterion (AIC) (Posada \& Buckley 2004). The models selected for $\mathrm{CO} 1$ for each partition block were $\mathrm{GTR}+\mathrm{G}+\mathrm{I}\left(1^{\text {st }}\right.$ and $2^{\text {nd }}$ codon positions) and $\mathrm{GTR}+\mathrm{G}\left(3^{\text {rd }}\right.$ codon position).

\section{P-distances under neighbor joining (NJ)}

The Bootstrap values in NJ analysis were calculated with the following commands: Number of replicates $=1000$, Bootstrap support values $=1000$ (significant values $\geq 50 \%$ ), Substitution type $=$ nucleotide, Method $=p$-distance, Substitution to Include $=\mathrm{d}$ : Trasitions + Transeversions, Rates among Sites $=$ Gamma distributed with Invariant sites $(\mathrm{G}+\mathrm{I})$, Missing Data Treatment $=$ Pairwise deletion, Select Codon Position $=1^{\text {st }}+2^{\text {nd }}$ and $3^{\text {rd }}$.

\section{General mixed yule coalescent model (GMYC)}

The GMYC species delimitation method applies single (Pons et al. 2006) or multiple (Monaghan et al. 2009) time thresholds to delimit species in a Maximum Likelihood context, using ultrametric trees (Pons et al. 2006; Ortiz \& Francke 2016). Phylogenetic analyses were run in BEAST ver. 2.6.0 (Drummond et al. 2012) using a coalescent (constant population) tree prior. As independent lognormal relaxed clock was applied to each partition, and analyses of $20 \times 106$ generations were run. Convergence was assessed with TRACER ver. 1.6 (Rambaut \& Drummond 2014). TreeAnnotator ver. 2.6.0 (BEAST package) (Rambaut \& Drummond 2014) was used to build maximum clade credibility trees, after discarding the first $25 \%$ of generations as burn-in. Following gene tree inference, GMYC was implemented in the web interface for single and multiple threshold GMYC (https://species.h-its.org/gmyc/). The backend 
of this web server runs the original R implementation of the GMYC model authored by Fujisawa \& Barraclough (2013).

\section{Automatic Barcode Gap Discovery (ABGD)}

The ABGD species delimitation method uses recursive partitioning with a range of prior intraspecific divergence and relative gap widths, estimating the threshold between intra- and interspecific genetic variation, generating species-level groupings (Ortiz \& Francke 2016). ABGD analyses were conducted using both uncorrected and K2P distance matrices with default options: Pmin $=0.001$, Pmax $=0.1$, Steps $=10$, Relative gap width $(X)=1, \mathrm{Nb}$ bins $=20$. The PTP species delimitation method (Zhang et al. 2013) is similar to GMYC, but uses substitution calibrated (not ultrametric) trees to avoid the potential flaws in constructing time calibrated phylogenies (Zhang et al. 2013; Ortiz \& Francke 2016).

\section{Bayesian Poisson Tree Process (bPTP)}

The Bayesian variant of the method (bPTP) was employed in the online version (https://species.h-its.org/ptp/). It was run on the Bayesian gene trees with default options: rooted tree,

KR180433.1 Pseudocellus giribeti 80091 Triunfo Chis.

KR180426.1 Pseudocellus giribeti $798914 \mathrm{~km}$ SE Custepec Chis.

KR180434.1 Pseudocellus giribeti 80112 Triunfo Chis.

KR180435.1 Pseudocellus giribeti 80243 Triunfo Chis.

KR180450.1 Pseudocellus giribeti $79799.43 \mathrm{~km}$ SE Custepec Chis. KR180452.1 Pseudocellus giribeti $79891.14 \mathrm{~km}$ SE Custepec Chis. KR180453.1 Pseudocellus giribeti $79891.24 \mathrm{~km}$ SE Custepec Chis. KR180454.1 Pseudocellus giribeti $9891.34 \mathrm{~km}$ SE Custepec Chis. KR180455.1 Pseudocellus giribeti $79891.44 \mathrm{~km}$ SE Custepec Chis. KR180456.1 Pseudocellus giribeti $79891.54 \mathrm{~km}$ SE Custepec Chis. KR180457.1 Pseudocellus giribeti 79966.1 Triunfo Chis. KR180458.1 Pseudocellus giribeti 80001.1 Triunfo Chis. KR180459.1 Pseudocellus giribeti 80001.2 Triunfo Chis.

JX951411.1 Pseudocellus giribeti $797993 \mathrm{~km}$ SE Custepec Chis.

68 KR180449.1 Pseudocellus sp. 99190 Honduras

[ KR180444.1 Pseudocellus sp. 83165 Guatemala 1

99 , KR180445.1 Pseudocellus sp. 89406 Guatemala 1

69 KR180443.1 Pseudocellus sp. 99193 Guatemala 1

KR180442.1 Pseudocellus sp. 99283 Guatemala 2

KR180441.1 Pseudocellus sp. 89422 Guatemala 2

$99\left[\begin{array}{l}\text { KR180441.1 Pseudocellus sp. } 89422 \text { Guatemala } \\ \text { KR180447.1 Pseudocellus monjarazi } 136272]\end{array}\right.$

KR180438.1 Pseudocellus sp. 98418 Honduras KR180451.1 Pseudocellus boneti 130046.2

99 KR180446.1 Pseudocellus boneti 130046

KR180440.1 Pseudocellus sp. 89548 Guatemala 3

99 KR180439.1 Pseudocellus sp. 89536 Guatemala 3 KR180448.1 Pseudocellus sbordonii 136270 ] KR180436.1 Pseudocellus gertschi 130036 ] KR180469.1 Ricinoides feae

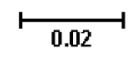

Fig. 1. Neighbour-Joining (NJ) tree with $p$-distances constructed with $C O I$ barcode sequences from different specimens and species of Pseudocellus Platnick, 1980. Colors of the branches indicate species of Pseudocellus already described, red branches indicate the new species. Numbers on the branches represent Bootstrap support values ( $>50 \%$ significant). 
MCMC generations $=100000$, Thinning $=100$, Burn-in $=0.1$, Seed $=123$. The trees generated were edited using Adobe Photoshop CS6.

\section{Assemble Species by Automatic Partitioning (ASAP)}

The ASAP species delimitation method proposes partitions of species hypotheses using genetic distances calculated between DNA sequences (Puillandre et al. 2021). ASAP analyses were conducted using Kimura (K80) distance matrices ts/tv: 2.0.

\section{Results}

\section{Molecular analyses and species delimitation}

The analyzed matrix of $\mathrm{CO} 1$ includes 30 terminals (including one outgroup) and 655 aligned characters. Specimens used in this study, GenBank accession numbers and localities of the sequences used are listed in Table 1. The multiple molecular methods consistently separate the new species

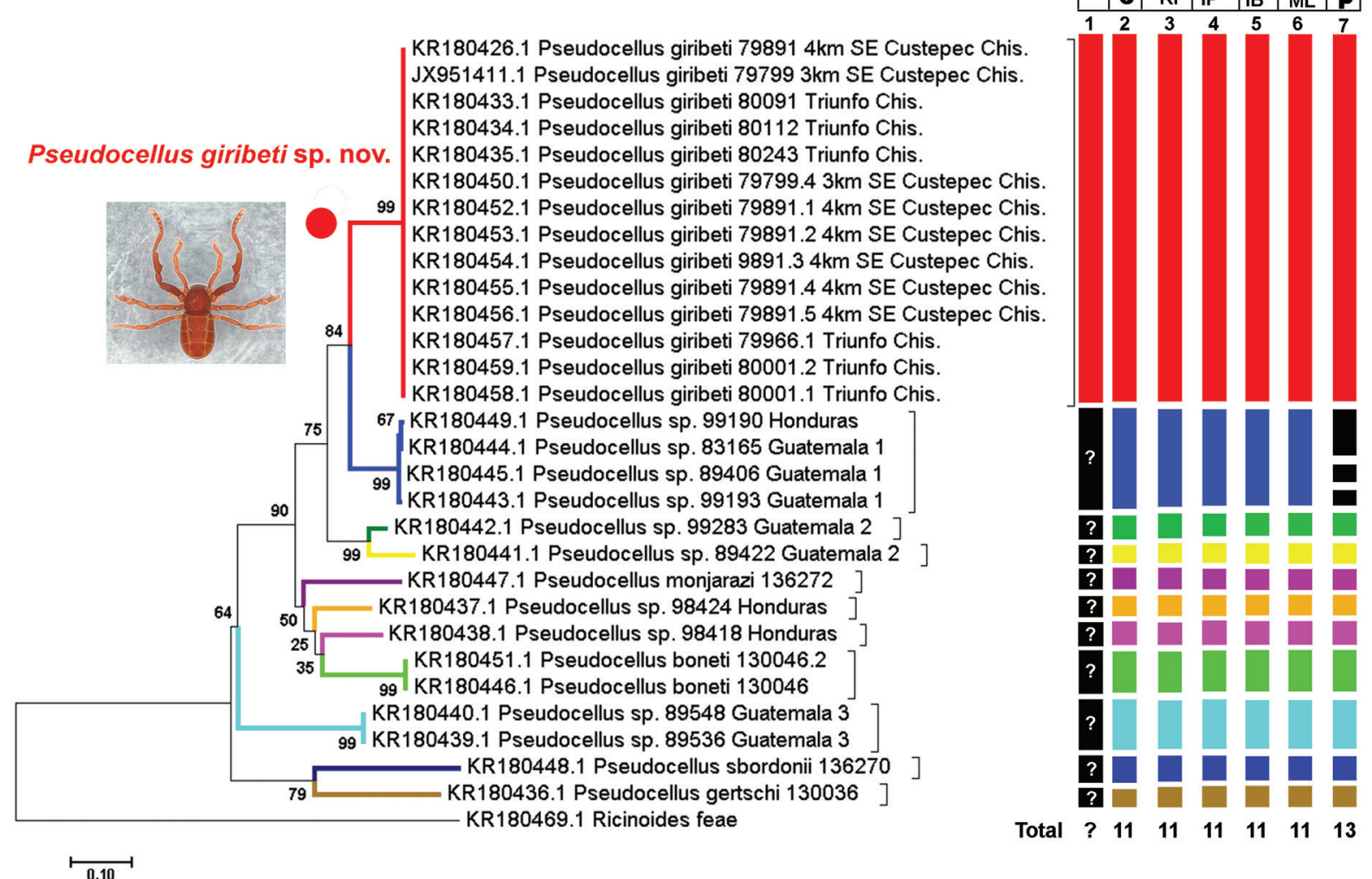

Fig. 2. Maximum Likelihood gene tree (highest log: -3134.13), constructed with COI barcode sequences of Pseudocellus Platnick, 1980. Colors of the branches indicate species; same colors are in the bars, which represent the different species delimitation methods used for their validation. Red branches + red circle indicate the new species described herein. Numbers below the bars represent the number of species recovered under each species delimitation method (not considering the outgroup: Ricinoides feae (Hansen, 1921)): 1: morphology (M). 2: GMYC. 3: ABGD with recursive partitions (RP). 4: ABGD with initial partitions (IP). 5: bPTP with IB. 6: bPTP with ML. 7: ASAP. Numbers on the branches are Bootstrap support values ( $>50 \%$ significant). 


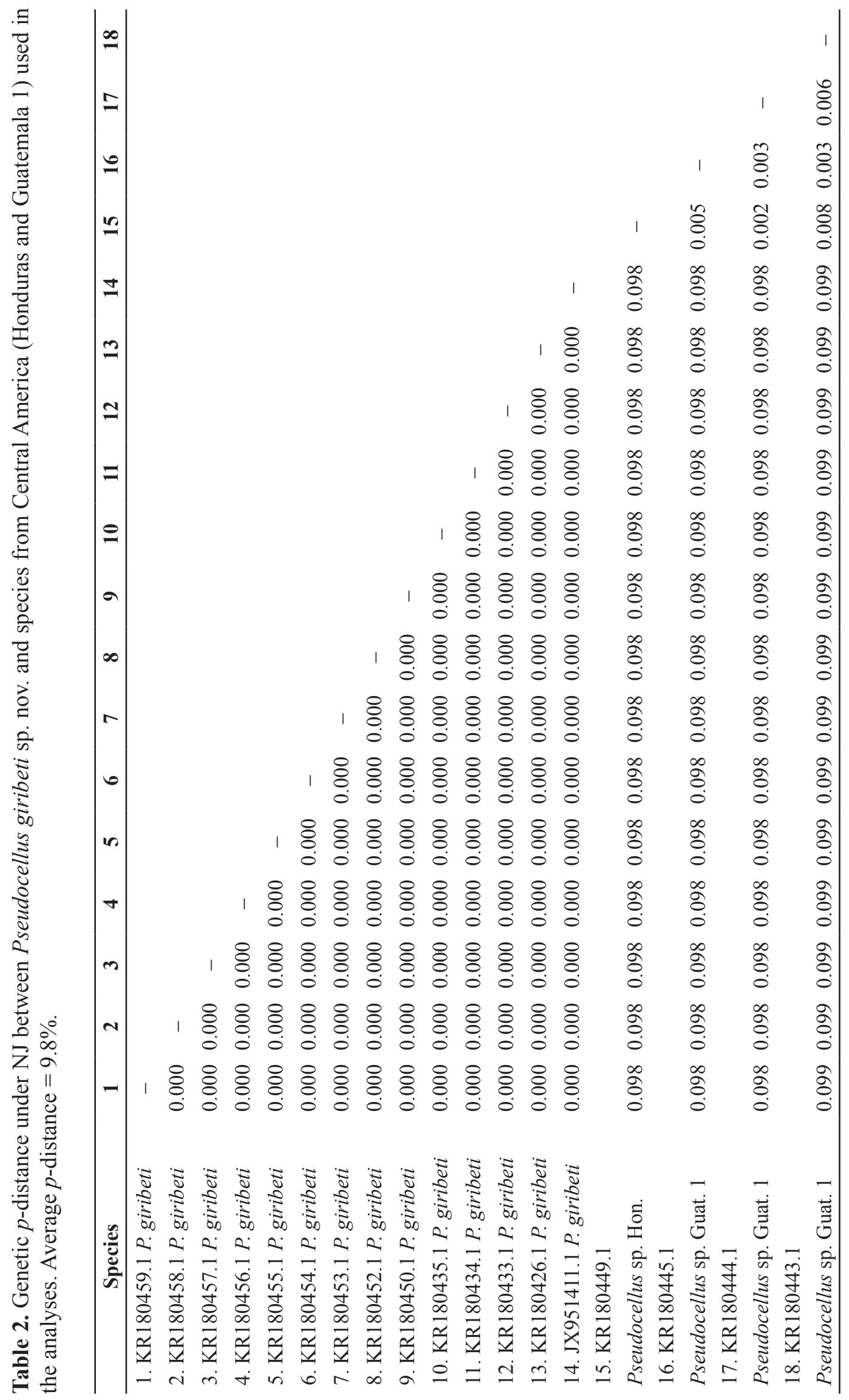


(congruence among methods) and according to the morphology of sexual structures traditionally used for identification and delimitation at the species level in ricinuleids (copulatory apparatus of leg III of the male, femur and tibia II of the male and female spermathecae) (Figs 13-14, 20-26, 29-31). Although the morphology was not checked for the other species included in the molecular analyses (Fig. 2), the multiple molecular methods consistently separate the rest of the species (Fig. 2). The average genetic distance under NJ among analyzed species of Pseudocellus was $11.6 \%$. Bootstrap support values were high for the new species (99\%) (Fig. 1). Pseudocellus giribeti sp. nov. is closely related to the putative species composed by specimens of Guatemala 1 and Honduras (Fig. 1; Fig. 2, blue branch) with an average $p$-distance of $9.8 \%$ between both species (Table 2 ).

Initially, GMYC was proposed by Pons et al. (2006) as a molecular method for species delimitation in a Maximum Likelihood context and based on ultrametric trees. The method was found to be robust in a range of departures from its simplifying assumptions (Fujisawa \& Barraclough 2013; Talavera et al. 2013). Herein, this species delimitation method was robust and concordant for the analyzed species of Pseudocellus, recovering the new species based on traditional morphology (Fig. 2). ABGD is a molecular species delimitation method that uses cursive partitioning, with a range of prior intraspecific divergence and relative gap width, to estimate the threshold between intra- and interspecific variation and then intends to produce species-level groupings (Ortiz \& Francke 2016; Valdez-Mondragón 2020). However, this species delimitation method is sensitive to sampling effect, as was demonstrated in the spider genera Aphonopelma Pocock, 1901 and Bonnetina Vol, 1999 from North America by Hamilton et al. (2014) and Ortiz \& Francke (2016), respectively, tending to give moderately over-splitting solutions. In this work, the ABGD method was consistent in separating Pseudocellus giribeti sp. nov. with recursive partitions (RP) and initial partitions (IP), and the species is recovered as one single species, which corresponds and is concordant with the morphology (Fig. 2). PTP is similar to GMYC but uses substitution calibrated (not ultrametric) trees to avoid the potential flaws in constructing time-calibrated phylogenies, as was proposed by Zhang et al. (2013). In this work, we employed the Bayesian variant of the method (bPTP), which was also concordant with morphology and the other molecular methods, recovering a total of 11 species (Fig. 2). The ASAP is a species delimitation method that proposes partitions of species hypotheses using genetic distances, which are calculated between DNA sequences (Puillandre et al. 2020). This method is similar to ABGD, using cursive partitioning with a range of prior intraspecific divergence and relative gap width, which is used to estimate the threshold between intra- and interspecific variation, producing species-level groupings. This method also recovers the new species Pseudocellus giribeti sp. nov. (Fig. 2). However, this method was discordant with the other methods, over-estimating the number of total number of species as 13 in the case of the samples from Guatemala 1 (KR180443.1-KR180445.1) and Honduras (KR180449.1), which are considered as three species under this approach (Fig. 2).

\section{Taxonomy}

Clase Arachnida Cuvier, 1812

Order Ricinulei Thorell, 1876

Suborder Neoricinulei Selden, 1992

Superfamily Ricinoidoidea Ewing, 1929

Family Ricinoididae Ewing, 1929

Genus Pseudocellus Platnick, 1980

\section{Type species}

Cryptocellus dorotheae Gertsch \& Mulaik, 1939. 


\section{Pseudocellus giribeti sp. nov. urn:1sid:zoobank.org:act:685BFED1-4CC2-4DD4-BA1F-E829799BE8C7}

Figs 3-35

\section{Differential diagnosis}

Pseudocellus giribeti sp. nov. resembles Pseudocellus alux Armas \& Agreda, 2016. However, several morphological differences distinguish both species. The opisthosoma of the male of P. giribeti sp. nov. is shorter and slightly oval (Fig. 1), whereas that of P. alux is slightly longer and less oval (Armas \& Agreda 2016: fig. b). The carapace in the new species is as short as in P. alux (Figs 3, 5). Males of the new species have the tibia of the pedipalp deeply curved on the prolateral part (Fig. 19), whereas in $P$. alux the tibia of the pedipalp is slightly curved (Armas \& Agreda 2016: fig. c). Males of $P$. giribeti sp. nov. and P. alux have a similar shape of femur II, but the males of the new species have a longer femur II than $P$. alux, with proportions of 3.45 and 2.17 times as long as wide, respectively (Fig. 17; Armas \& Agreda 2016: figs b, f). Males of $P$. giribeti sp. nov. and $P$. alux have a similar shape of tibia II, with two basal conical apophyses on tibia II, one proventral and the other retroventral (Figs 3-4, 13-14); however, in $P$. giribeti sp. nov. the tubercles are thinner and located at $1 / 3$ of the tibia length (Figs 13-14), whereas in $P$. alux the tubercles are wider and with a sharp tip, located at almost $1 / 2$ of the tibia length (Armas \& Agreda 2016: fig. f). The tarsal process $(t P)$ of male leg III of $P$. giribeti sp. nov. is slightly wider and less curved than in P. alux (Figs 21, 23, 25; Armas \& Agreda 2016: fig. e). The tip of the $t P$ is bifurcated in both species, but in the new species the lobule 1 (L1) is longer and thinner than in $P$. alux (Fig. 26; Armas \& Agreda 2016: fig. e). The metatarsal process $(m P)$ of males of $P$. giribeti sp. nov. is wider distally than in P. alux (Figs 20-21; Armas \& Agreda 2016: figs d-e). The lamina cyathiformis $(L c)$ of males of the new species is wide and straight dorsally (Figs 20-21), whereas in P. alux it is thinner and slightly curved dorsally (Armas \& Agreda 2016: figs d-e). Unfortunately, the spermathecae in P. alux were not dissected in the original description by Armas \& Agreda (2016), and therefore it is not possible to compare both species in this regard.

\section{Etymology}

This species is dedicated to Dr Gonzalo Giribet from Harvard University in recognition of his contribution to the knowledge of ricinuleid phylogenetics and the loan of the specimens.

\section{Type material}

\section{Holotype}

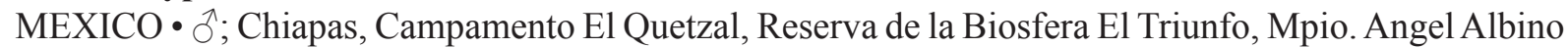
Corzo; $15.7221^{\circ}$ N, $92.9429^{\circ}$ W; 1820 m a.s.1.; 20 May 2008; R. Anderon leg.; MCZ 80010.

\section{Paratypes}

MEXICO $\bullet 14$ ๙ิ $\hat{0}, 10$ 우, 6 deutonymphs, 4 tritonymphs; same collection data as for holotype; MCZ $80010 \bullet 1 \hat{\jmath}$, same collection data as for holotype; CNAN-T01482 • 1 \% ; same collection data as for holotype; CNAN-T01483.

\section{Description}

Male (holotype, MCZ 80010)

Specimen collected manually, preserved, and observed in $80 \%$ ethanol.

Measurements (mm). Total length (carapace + opisthosoma including pygidium) 3.55. Carapace 1.30 long, 1.32 wide (widest part). Cucullus 0.60 long, 0.90 wide. Opisthosoma 2.36 long (not including pygidium), 1.68 wide (widest part). Femur II length/diameter (1/d): 3.17. Legs, tarsal formula (leg I to IV): $1-5-4-5$. Leg lengths; I: coxa 0.60 / trochanter $10.32 /$ trochanter 2 -/ femur 0.80 / patella $0.42 /$ 
tibia $0.66 /$ metatarsus $0.76 /$ tarsus $0.40 /$ total 3.96; II: $0.70 / 0.48 /-/ 1.32 / 0.72 / 1.08 / 1.12 / 1.25$ / 6.67; III: $0.62 / 0.33 / 0.37 / 0.90 / 0.50 / 0.57 / 0.68 / 1.09 / 5.06$; IV: 0.56/0.38/0.33/0.95/0.50/0.62/ 0.72/ 0.76/ 4.82. Leg length formula: 2-3-4-1.

Coloration. Cucullus, carapace and sternal region dark reddish (Figs 3-6). Legs I, III and IV lighter dark reddish than legs II; tarsomeres paler reddish than other segments. Opisthosoma reddish dorsally, darker ventrally on sternites XI and XII (Figs 7-8).
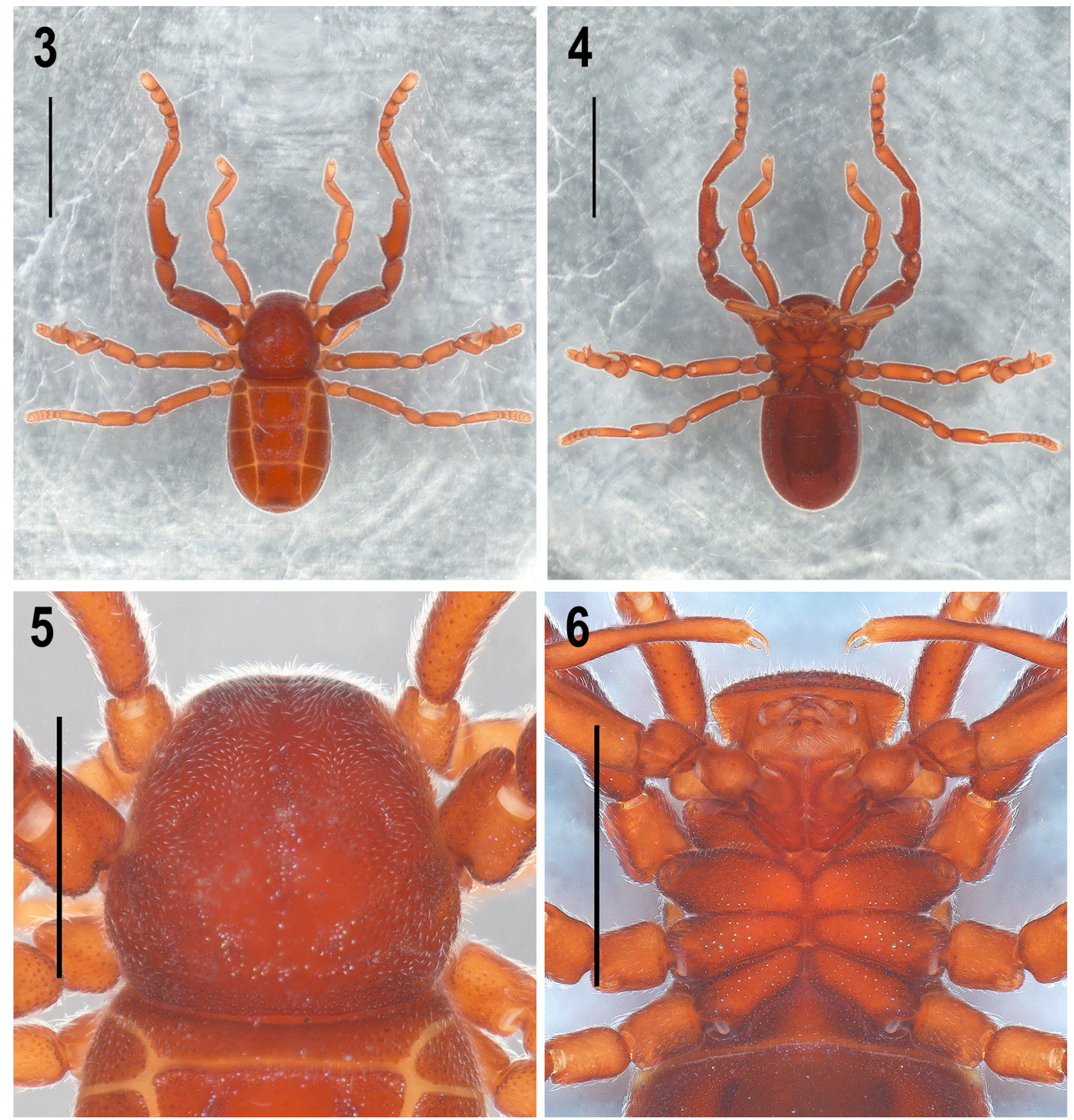

Figs 3-6. Pseudocellus giribeti sp. nov. Holotype, ô (MCZ 80010). 3-4. Habitus, dorsal and ventral views. 5. Carapace, dorsal view. 6. Prosoma, ventral view, showing coxosternal region. Scale bars: $3-4=2 \mathrm{~mm} ; 5-6=0.5 \mathrm{~mm}$. 
CARAPACE (Fig. 5). Slightly longer than wide, trapezoidal, widest at posterior margin between coxae II and III. Tegument covered with abundant, fine translucent setae and granules. Anterior margin straight, lateral margins not parallel, narrowing anteriorly; posterior margin procurved. Inconspicuous translucent areas present at level of trochanters II. Carapace with seven depressions: one median along, and three lateral depressions at level of each coxae III.

Cucullus (Fig. 11). As wide as long, widest distally; anterior margin straight, lateral margins rounded at anterior corners. Tegument covered with abundant translucent setae and granules similar to those on carapace. One slight depression each side close to anterior margin, cuticular pits absent. Distal margin with long, translucent setae.

Chelicerae (Fig. 12). Movable finger with eight teeth, basal one larger than others, which are equal in size. Fixed finger with five teeth, subequal in size, distal tooth longer. Both fingers with long translucent setae basally.
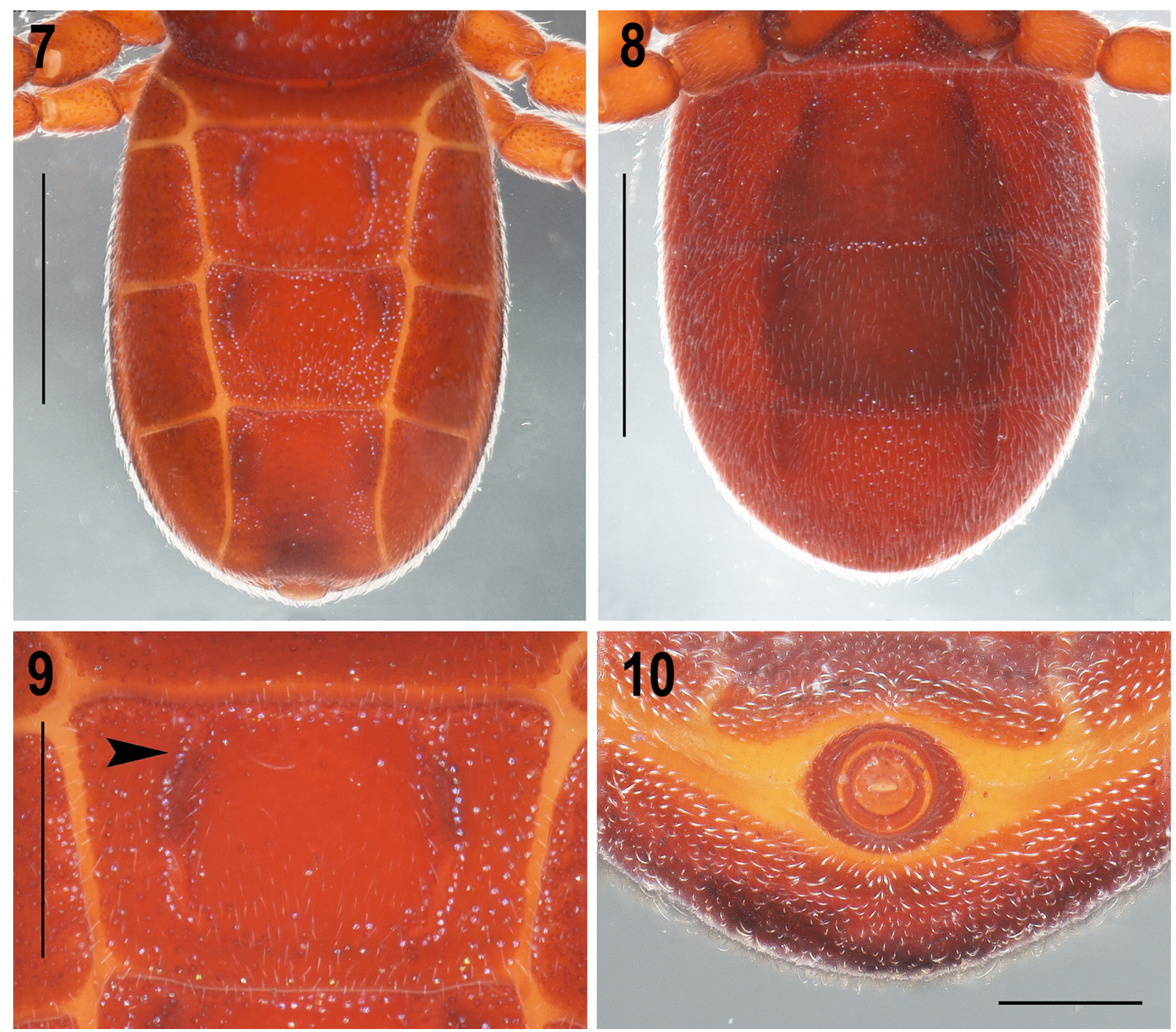

Figs 7-10. Pseudocellus giribeti sp. nov. Holotype, ô (MCZ 80010). 7-8. Opisthosoma, dorsal and ventral views. 9. Tergite XI, median plate (arrow indicates the lateral depression). 10. Pygidium, posterior view. Scale bars: $7-8=1 \mathrm{~mm} ; 9=0.5 \mathrm{~mm} ; 10=0.2 \mathrm{~mm}$. 

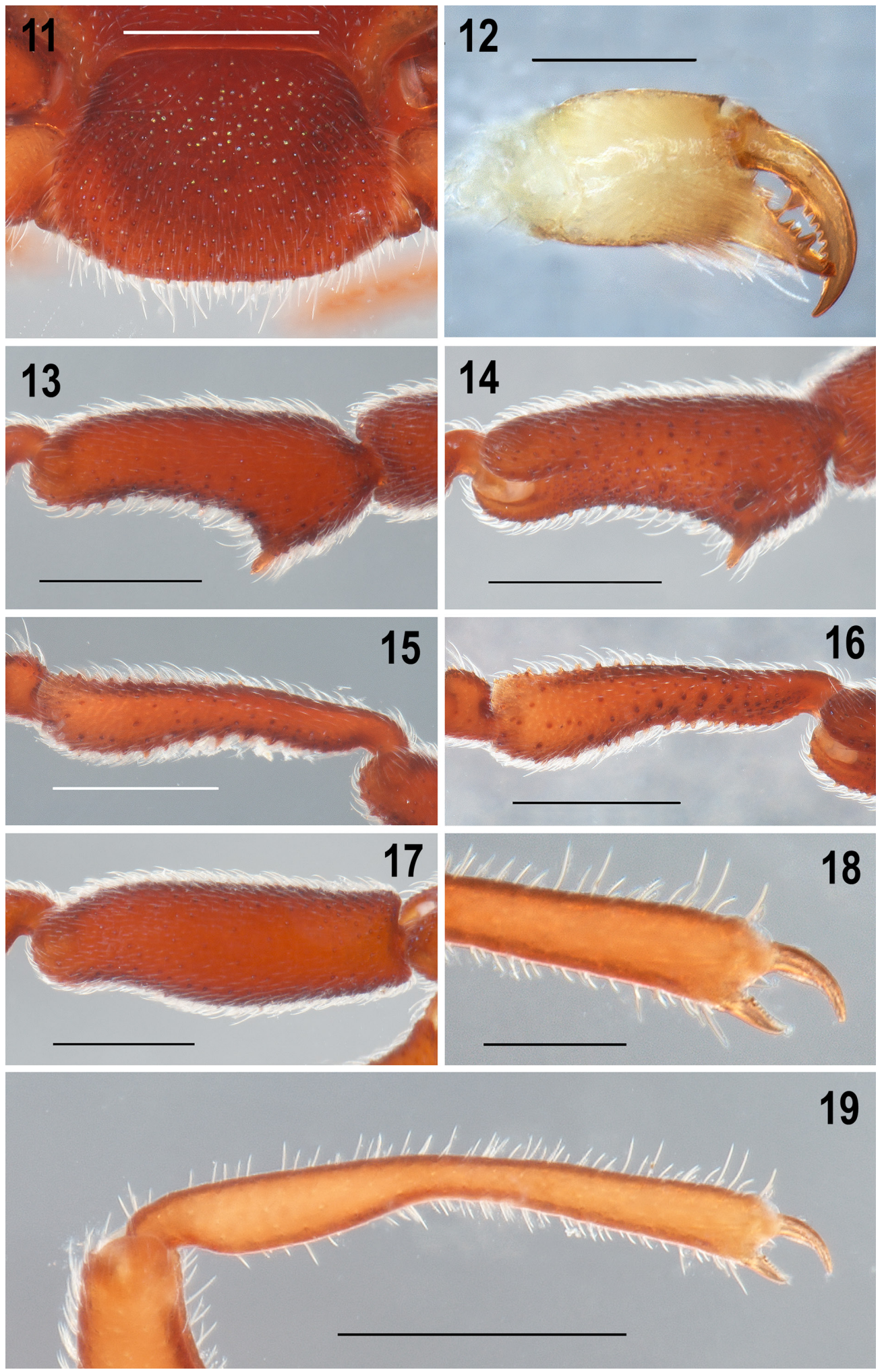

Figs 11-19. Pseudocellus giribeti sp. nov. Holotype, ổ (MCZ 80010). 11. Cucullus, dorsal view. 12. Left chelicera, dorsal view. 13-14. Right tibia II, prolateral and proventral views. 15-16. Right metatarsus II, prolateral and proventral views. 17. Right femur II, prolateral view. 18. Detail of the movable and fixed claws of the right pedipalp, retrolateral view. 19. Right pedipalp tibia, retrolateral view. Scale bars: 11, $13-17,19=0.5 \mathrm{~mm} ; 12=0.2 \mathrm{~mm} ; 18=0.1 \mathrm{~mm}$. 
Sternal Region (Fig. 6). Coxae covered with translucent setae and granules similar to those on carapace. Coxae I rhomboidal, II sub-rectangular, III and IV conical. Coxae II larger and wider than others, coxae IV smallest. Coxae II meeting tritosternum along $1 / 3$ of its length. Coxae II anterior and posterior margins perpendicular to median axis of prosoma; coxae III slightly oblique, their posterior margins forming an obtuse angle $\left(>90^{\circ}\right)$ with each other; coxae IV oblique, their posterior margins forming an obtuse angle (little more $>90^{\circ}$ ) with each other.

Opisthosoma (Figs 3-4, 7-8). Longer than wide, widest at level of tergites XII and XIII. Tegument covered with abundant setae and granules similar to those on carapace; cuticular pits absent. Median plates of tergites XI-XIII with paired longitudinal depressions, those of tergite XI the smallest. Tergite $\mathrm{X}$ widest and shortest. Median tergites XI and XII trapezoidal, wider than long; median tergite XIII slightly longer than wide, with posterior corners curved. Lateral tergites in oblique position; X smallest and XIII largest. Lateral tergites XI trapezoidal, XII square and XIII triangular. Sternites XI-XIII with paired depressions. Sternites XI and XII dark medially, XIII paler reddish. Pygidium segments without notch (Fig. 10).

Pedipalps (Figs 6, 18-19). Coxae with fine translucent setae and rounded granules. Trochanters 1 rounded, with sparse fine translucent setae and few granules restricted to ventrodistal half; trochanters 2 conical, ventrally with basal setae and granules (similar to those on $1^{\text {st }}$ ). Femora curved distally and wider proximally, without granules, with deep prolateral concavity distally close to tibial joint; tegument with abundant translucent setae, thinner and longer on prolateral and distal surfaces. Tibiae deeply curved on prolateral part, with numerous thin translucent setae longer distally. Tibiae without granules. Movable claws curved and longer than fixed claws, which are conical. Movable claws without teeth, fixed claws with small teeth.

Legs. Without cuticular pits but with translucent setae and rounded granules on all segments (Figs 3-4). Legs II noticeably longer and wider (Figs 3-4). Femora II almost straight, slightly curved on prolateraldistal part, wider and longer than the others; femora II ventrally with few scattered sharp-tipped granules (Fig. 17). Tibiae II ventrally with two sharp and small apophyses on basal part (Figs 3-4, 13-14). Metatarsus II with scattered sharp-tipped granules, not forming rows, ventral ones longer and more conspicuous than dorsal one, metatarsus curved ventrally (Figs 15-16). Tarsomeres of leg II dorsally with sharp-tipped granules, tarsomeres 5 with fewer granules not sharp-tipped. Femora I, III and IV ventrally with few sharp-tipped granules. Patellae I, III and IV with normal granules. Tibiae I, III and IV ventrally with few sharp-tipped granules distally. All metatarsi dorsally with V-shaped invaginations distally; metatarsi I, III and IV without granules ventrally, only few slightly sharp-tipped granules dorsodistally on metatarsi I and IV. Tarsomeres of legs I, III and IV without granules.

LegS III AND COPUlatoRY APPARATUS. Metatarsi almost square-shaped in prolateral view, with numerous long translucent setae; metatarsal processes $(m P)$ long and slightly sigmoidal in pro and retrolateral views (Figs 20-21), curved and hook-shaped in dorsal view (Fig. 22). Lamina cyathiformis $(L c)$ of tarsomeres 2 leaf shaped, with a small notch basally in retrolateral view (Fig. 20), $L c$ with long translucent setae throughout. All tarsomeres ventrally with long translucent setae, which are more numerous and longer on tarsomere 4. Tarsomeres 4 with two curved claws (Figs 20-22). Copulatory apparatus sigmoid shaped in dorsal view (Fig. 24), with tarsal process $(t P)$ curved, arc-shaped (Figs 23, 25); accessory piece (ac) of copulatory apparatus curved, with sharp tip (Fig. 23). Tip of the $t P$ bifurcated, with a long and conical lobule 1 (L1) (Fig. 26).

Female (Paratype, MCZ 80010)

Specimen collected manually, preserved and observed in $80 \%$ ethanol. 

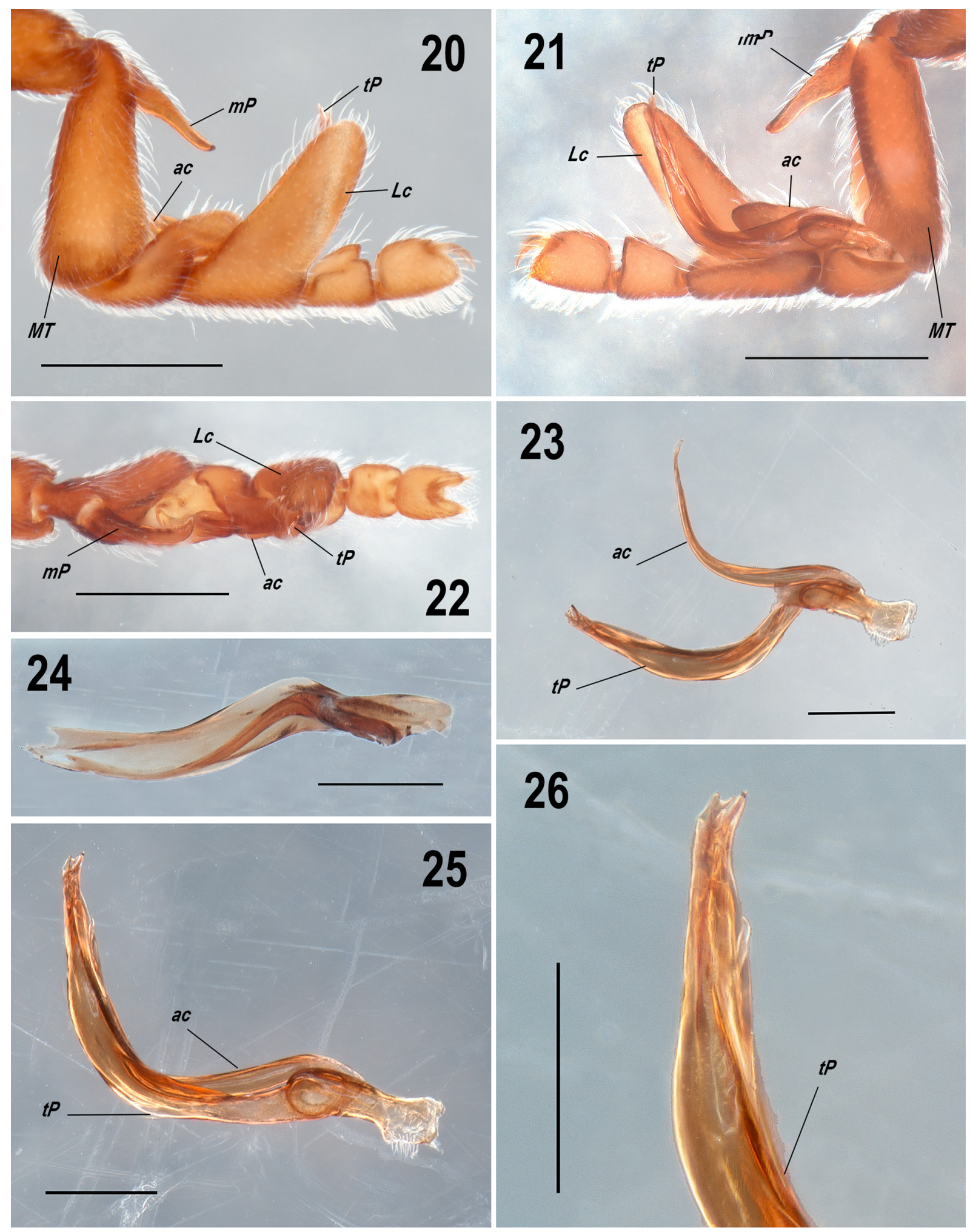

Figs 20-26. Pseudocellus giribeti sp. nov. Holotype, ô (MCZ 80010). 20-22. Right leg III (copulatory apparatus), retrolateral, prolateral and dorsal views. 23. Copulatory apparatus extended, prolateral view. 24. Copulatory apparatus, dorsal view. 25. Copulatory apparatus, prolateral view. 26. Tarsal process, distal half, prodorsal view. Scale bars: $20-22=0.5 \mathrm{~mm} ; 23-25=0.2 \mathrm{~mm} ; 26=0.1 \mathrm{~mm}$. 
MEasurements. Total length (carapace + opisthosoma including pygidium) 3.70. Carapace 1.32 long, 1.44 wide. Cucullus 0.60 long, 0.87 wide. Opisthosoma 2.46 long (not incluiding pygidium), 1.84 wide (widest part). Femur II length/diameter (1/d): 3.71. Legs, tarsal formula (leg I to IV): 1-5-4-5. Leg lengths; I: coxa 0.61 / trochanter $10.32 /$ trochanter 2 -/ femur 0.76 / patella $0.42 /$ tibia $0.60 /$ metatarsus $0.77 /$ tarsus $0.24 /$ total 3.72; II: $0.77 / 0.44 /-/ 1.24 / 0.65 / 1.01 / 1.11 / 1.25 / 6.47$; III: $0.66 / 0.38 / 0.37 /$ 0.88/ 0.50/ 0.62/ 0.71/ 0.66/4.78; IV: 0.61/ 0.43/ 0.41/ 0.95/ 0.51/ 0.66/ 0.72/ 0.66/ 4.95. Leg length formula: $2-4-3-1$.

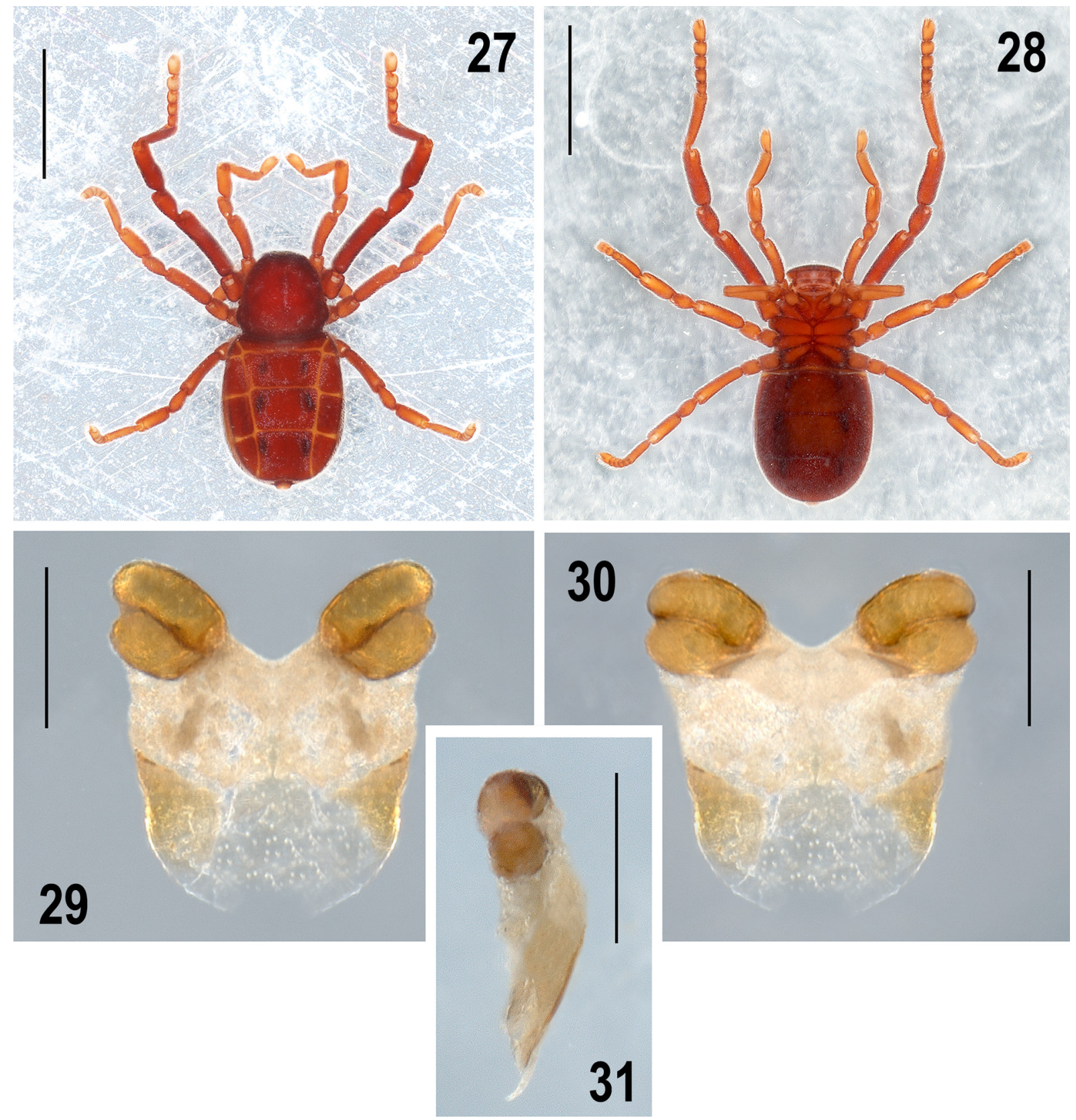

Figs 27-31. Pseudocellus giribeti sp. nov. Paratype, $\bigcirc$ (MCZ 80010). 27-28. Habitus, dorsal and ventral views. 29-31. Spermathecae, anterior, posterior and lateral views, respectively. Scale bars: $27-28=$ $2 \mathrm{~mm} ; 29-31=0.2 \mathrm{~mm}$. 
Differs from male as follows: carapace paler reddish, median longitudinal depression shallower than on male. Femora II less robust than those on male. Tibiae II without ventral conical apophyses, but with some sharp-tipped granules, femora II slightly curved on prolateral-distal part. Metatarsus II with the scattered sharp-tipped granules smaller than those on male. Metatarsus II straight. Opisthosoma wider, higher and larger than in male, paler reddish (Figs 27-28). Median tergites X-XIII wider than those on male (Fig. 27). Spermathecae with two oval lobules on each side, one as long as the other, with widespread tiny pores throughout (Figs 29-31).
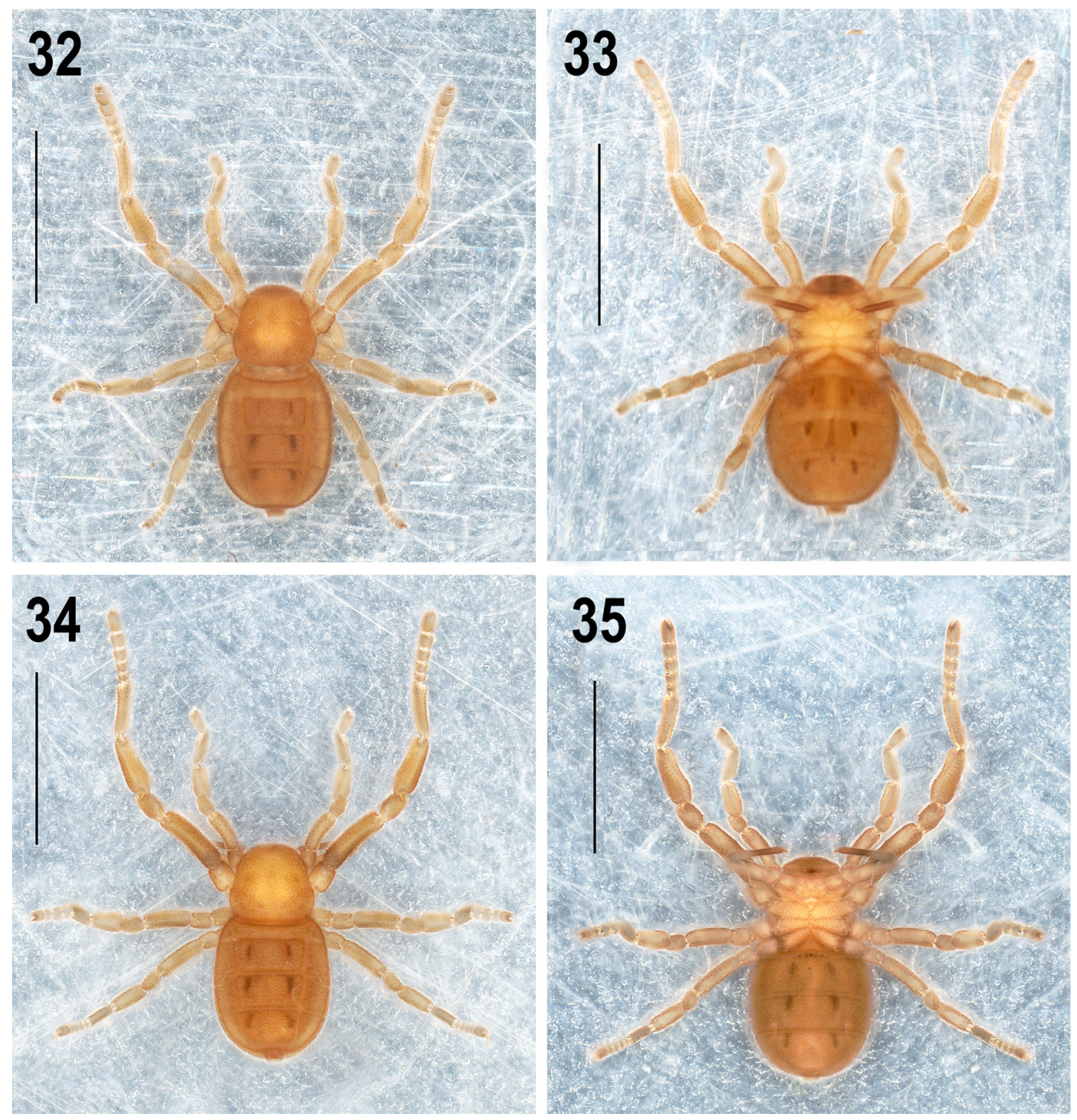

Figs 32-35. Pseudocellus giribeti sp. nov. Paratypes (MCZ 80010). 32-33. Deutonymph, habitus, dorsal and ventral views. 34-35. Tritonymph, habitus, dorsal and ventral views. Scale bars $=2 \mathrm{~mm}$. 


\section{Natural history}

The specimens were collected manually in oak forest litter.

\section{Distribution}

Mexico: Chiapas (Fig. 36).

\section{Discussion}

The taxonomic science has at least three distinct very important roles in biology: 1) the assignment of individual organisms into pre-existing species categories (species assignment), 2) the assignment of species to higher categories (genus, family, orders, etc), and 3) the designation of new species categories to clasify individual specimens that do not fit into an existing species category (species delimitation) (Rannala \& Yang 2020). Traditionally, all this three roles have been performed by taxonomists using morphological characters in the majority of the cases. Modern taxonomy is changing, and currently uses multiple lines of evidence for species identification and delimitation (Valdez-Mondragón et al. 2019; Valdez-Mondragón 2020). DeSalle et al. (2005) mentioned that there are currently two important

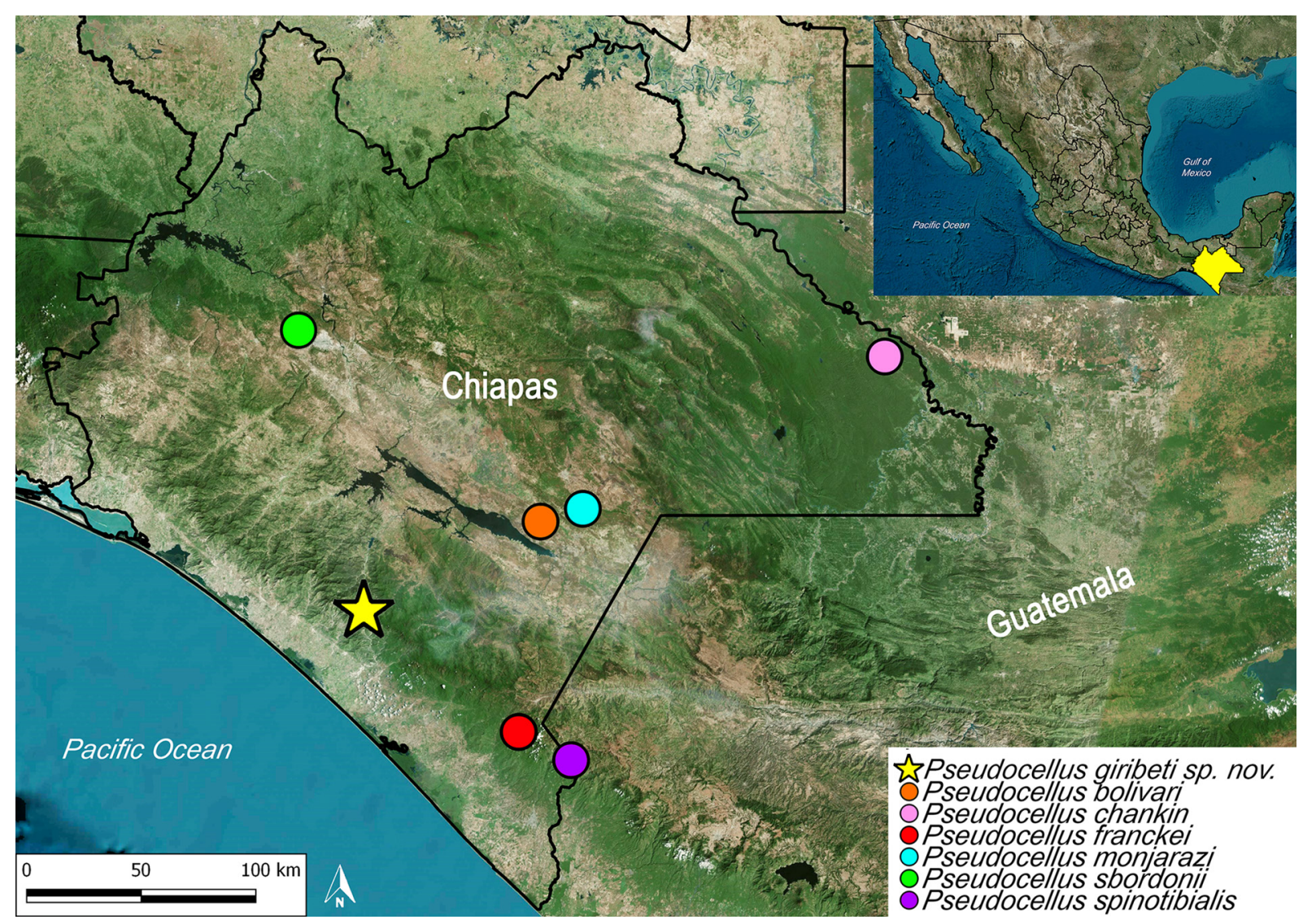

Fig. 36. Species of the genus Pseudocellus Platnick, 1980 described from Chiapas, Mexico, including the new species described herein. Star: El Triunfo Biosphere Reserve, El Quetzal Camp, Angel Albino Corzo Municipality. Red circle: Cerro Boquerón, Ejido Boquerón, Motozintla Municipality. Orange circle: Sumidero del Camino, 16 km NE of Comitán. Pink circle: Kolem-chen Cave "Cueva Grande", Chan-kin Reserve, Ocosingo Municipality. Blue circle: San Francisco Cave, La Trinitaria Municipality. Purple circle: Finca Guatimoc, south slope of the Tacaná volcano, $32 \mathrm{~km}$ north of Tapachula, near Cacahuatán. Green circle: Las Abejas Cave, San Fernando Municipality. 
tasks to which DNA barcodes markers are being deeply applied in modern systematics and taxonomy, first distinguishing between 'sibling' species (equivalent to species identification or species diagnosis), and second, the use of molecular data to discover underestimated biodiversity (equivalent to species delimitation and species description). How species boundaries are fixed is a central debate in modern systematics, which has generated multiple molecular delimitation methods based on heuristic and parametric methods tending to solve the inconsistencies in classical taxonomy (Hamilton et al. 2011, 2014, 2016; Ortiz \& Francke 2016; Rannala \& Yang 2020). The use of the mitochondrial cytochrome $c$ oxidase subunit 1 (CO1) barcode gene has become useful as the standard animal barcoding marker in many taxonomic studies, including arachnids (Hebert et al. 2003, 2004; Astrin et al. 2006; CorreaRamírez et al. 2010; Hamilton et al. 2011, 2014, 2016; Graham et al. 2015; Planas \& Ribera 2015; Ortiz \& Francke 2016; Tahami et al. 2017; Cruz-López et al. 2019; Valdez-Mondragón et al. 2019; ValdezMondragón 2020). However, the use of mitochondrial markers alone may lead to the overestimation of taxonomic diversity, as has been demonstrated in some tarantula genera (Ortiz \& Francke 2019). In modern taxonomy, the use of multiple evidence is generally accepted and currently common such as morphology and molecular data (integrative taxonomy), which is more effective in the diagnosis, delimitation, and even the description of species. Recently, molecular species delimitation methods have provided a new way to resolve problems by using the infraspecific genealogical information, extensively using DNA barcoding markers (Hebert et al. 2003; DeSalle et al. 2005).

The CO1 barcode gene had never been tested previously for the molecular species delimitation of ricinuleids. However, this mitochondrial marker was used for the first molecular phylogeny of Ricinulei by Murienne et al. (2012) and the first phylogenomic study of the order by Fernández \& Giribet (2015). In the present study, $\mathrm{CO} 1$ showed a good resolution at the species level, with an average genetic distance among the analyzed species of $11.6 \%$ and high Bootstrap support values for the new species (Figs 1-2). Also, the average intraspecific genetic distance is less than $1 \%$, concordant with the morphology for most of the species delimitation methods. However, the molecular analyses are based only on a single mitochondrial molecular marker, so is not possible to establish phylogenetic relationships among the studied species that do not include all the species from Central America. The morphology of sexual structures used for identification, diagnosis, and delimitation at the species level in ricinuleids is still strong evidence for the delimitation of species. Structures such as the copulatory apparatus of leg III of the male, femur and tibia II of the male, and female spermathecae are robust morphological characters for the identification at the species level. In the case of the accessory piece of the copulatory apparatus (Figs 20-26), the shape and distal bifurcation seems to be specific for each single species, including the three genera, Pseudocellus, Cryptocellus and Ricinoides (Tuxen 1974; Botero-Trujillo \& Pérez 2008, 2009; Tourinho \& Saturnino 2010; Pinto-da-Rocha \& Andrade 2012; Botero-Trujillo \& ValdezMondragón 2016; Botero-Trujillo \& Flórez 2017; Botero-Trujillo et al. 2021a, 2021b). Additionally, sexual structures are informative at the species level, such as female spermathecae, of which the shape and the number of lobules on each side are diagnostic characters (Figs 29-31). The shape of the tibia II of the males of Pseudocellus also seems to be a diagnosis character (Figs 3-4, 13-14), although many species have similar apophyses. Perhaps a combination of sexual morphological and molecular data in a phylogenetic analysis is required to test the monophyly of the genera if the generic diversity is underestimated. Even with only a few molecular markers such as CO1, the monophyly of Cryptocellus was not recovered, which was demonstrated by Fernández \& Giribet (2015).

Despite the growing knowledge of the diversity of the genus Pseudocellus in the last 10 years by ValdezMondragón \& Francke $(2011,2013)$, Valdez-Mondragón et al. $(2018,2020)$ and Valdez-Mondragón \& Juárez-Sánchez (2021), the diversity of the genus in Mexico is still poorly known. Intensive sampling is needed to know the diversity of ricinuleids. Mexico hosts the largest number of known troglobitic ricinuleids so far, which indicates that caves in Mexico could be a significant source of new species, where some species of Pseudocellus are common and often collected. 


\section{Acknowledgements}

The first author thanks the program "Cátedras CONACyT", Consejo Nacional de Ciencia y Tecnología (CONACyT), Mexico, for scientific support for project No. 59: "Laboratorio Regional de Biodiversidad y Cultivo de Tejidos Vegetales (LBCTV) del Instituto de Biología (IBUNAM), Tlaxcala". We thanks the Secretaría de Fomento Agropecuario del Estado de Tlaxcala (SEFOA), and the Government of the state of Tlaxcala for their consideration and support towards this research. We also thank to the reviewers for their comments and suggestions that improved our manuscript, Dr Gonzalo Giribet (Harvard University) for the loan of the specimens, and Cheryl Harleston for the English language review of the manuscript.

\section{References}

Armas L.F. 2017. Cuatro especies nuevas de Pseudocellus de Cuba (Arachnida: Ricinulei). Revista Ibérica de Aracnología 30: 87-99.

Armas L.F. \& Agreda E.O. 2016. Una nueva especie de Pseudocellus (Ricinulei: Ricinoididae) del Suroeste de Guatemala. Revista Ibérica de Aracnología 28: 79-83.

Astrin J.J., Huber B.A., Misof B. \& Kluetsch C.F. 2006. Molecular taxonomy in pholcid spiders (Pholcidae, Araneae): evaluation of species identification methods using CO1 and 16S rRNA. Zoologica Scripta 35 (5): 441-457. https://doi.org/10.1111/j.1463-6409.2006.00239.x

Bolívar y Pieltain C. 1946. Hallazgo de un nuevo Ricinulideo en el México Central. Ciencia 7:24-28.

Botero-Trujillo R. \& Flórez D.E. 2017. Two new ricinuleid species from Ecuador and Colombia belonging to the peckorum species-group of Cryptocellus Westwood (Arachnida, Ricinulei). Zootaxa 4286 (4): 483-498. https://doi.org/10.11646/zootaxa.4286.4.2

Botero-Trujillo R. \& Pérez G.A. 2008. A new species of Cryptocellus (Arachnida, Ricinulei) from northwestern Colombia. Journal of Arachnology 36: 468-471. https://doi.org/10.1636/CH07-95SC.1

Botero-Trujillo R. \& Pérez G.A. 2009. A new species of Cryptocellus (Arachnida, Ricinulei) from the Kofán Territory in southwestern Colombia. Zootaxa 2050 (1): 56-64.

https://doi.org/10.11646/zootaxa.2050.1.3

Botero-Trujillo R. \& Valdez-Mondragón A. 2016. A remarkable new species of the magnus speciesgroup of Cryptocellus (Arachnida, Ricinulei) from Ecuador, with observations on the taxonomy of the New World genera. Zootaxa 4107 (3): 321-337. https://doi.org/10.11646/zootaxa.4107.3.2

Botero-Trujillo R., Sain C.E. \& Prendini L. 2021a. Systematics of the "giant" ricinulei (Ricinoididae: Ricinoides) of West Africa, with descriptions of five new species and comparative morphology of the male copulatory apparatus. Bulletin of the American Museum of Natural History 448 (5): 1-68. https://doi.org/10.1206/0003-0090.448.1.1

Botero-Trujillo R., Carvalho L., Florez E. \& Prendini L. 2021b. Four new species of "hooded tickspiders" (Ricinulei, Ricinoididae) from South and Central America, with clarification of the identity of Cryptocellus leleupi Cooreman, 1976. American Museum Novitates 3976: 1-35.

https://doi.org/10.1206/3976.1

Brignoli P.M. 1974. On some Ricinulei of Mexico with notes of the morphology of the female genital apparatus (Arachnida, Ricinulei). Accademia Nazionale dei Lincei, Quaderno 171: 153-174.

Carstens B.C., Pelletier T.A., Reid N.M. \& Satler J.D. 2013. How to fail at species delimitation. Molecular Ecology 22 (17): 4369-4383. https://doi.org/10.1111/mec.12413

Correa-Ramírez M.M., Jiménez M.L. \& García-De León F.J. 2010. Testing species boundaries in Pardosa sierra (Araneae: Lycosidae) using female morphology and COI mtDNA. The Journal of Arachnology 38 (3): 538-554. https://doi.org/10.1636/Sh09-15.1 
Cruz-Lopez J.A., Monjaraz-Ruedas R. \& Francke O.F. 2019. Turning to the dark side: evolutionary history and molecular species delimitation of a troglomorphic lineage of armoured harvestman (Opiliones: Stygnopsidae). Arthropod Systematics and Phylogeny 77 (2): 285-302. https://doi.org/10.26049/ASP77-2-2019-06

DeSalle R., Egan M.G. \& Siddall M. 2005. The unholy trinity: taxonomy, species delimitation and DNA barcoding. Philosophical Transactions of the Royal Society B: Biological Sciences 360 (1462): 1905-1916. https://doi.org/10.1098/rstb.2005.1722

Drummond A.J., Suchard M.A., Xie D. \& Rambaut A. 2012. Bayesian phylogenetics with BEAUti and the BEAST 1.7. Molecular Biology and Evolution 29 (8): 1969-1973.

https://doi.org/10.1093/molbev/mss075

Ewing H.E. 1929. A synopsis of the American arachnids of the primitive order Ricinulei. Annals of the Entomological Society of America 22 (4): 583-600. https://doi.org/10.1093/aesa/22.4.583

Fernández R. \& Giribet G. 2015. Unnoticed in the tropics: phylogenomic resolution of the poorly known arachnid order Ricinulei (Arachnida). Royal Society Open Science 2 (6): e150065.

https://doi.org/10.1098/rsos.150065

Fujisawa T. \& Barraclough T.G. 2013. Delimiting species using single-locus data and the Generalized Mixed Yule Coalescent approach: a revised method and evaluation on simulated data sets. Systematic Biology 62 (5): 707-724. https://doi.org/10.1093/sysbio/syt033

Gertsch W.J. 1971. Three new ricinuleids from Mexican caves (Arachnida, Ricinulei). Bulletin of the Association for Mexican Cave Studies 4: 127-135.

Gertsch W.J. \& Mulaik S. 1939. Report on a new ricinuleid from Texas. American Museum Novitates 1037: 1-5. Available from http://hdl.handle.net/2246/4823 [accessed 8 Oct. 2021].

Graham M.R., Hendrixson B.E., Hamilton C.A. \& Bond J.E. 2015. Miocene extensional tectonics explain ancient patterns of diversification among turret-building tarantulas (Aphonopelma mojave group) in the Mojave and Sonoran deserts. Journal of Biogeography 42 (6): 1052-1065.

https://doi.org/10.1111/jbi.12494

Hamilton C.A., Formanowicz D.R. \& Bond J.E. 2011. Species delimitation and phylogeography of Aphonopelma hentzi (Araneae, Mygalomorphae, Theraphosidae): cryptic diversity in North American tarantulas. PloS One 6 (10): e26207. https://doi.org/10.1371/journal.pone.0026207

Hamilton C.A., Hendrixson B.E., Brewer M.S. \& Bond J.E. 2014. An evaluation of sampling effects on multiple DNA barcoding methods leads to an integrative approach for delimiting species: a case study of the North American tarantula genus Aphonopelma (Araneae, Mygalomorphae, Theraphosidae). Molecular Phylogenetics and Evolution 71: 79-93. https://doi.org/10.1016/j.ympev.2013.11.007

Hamilton C.A., Hendrixson B.E. \& Bond J.E. 2016. Taxonomic revision of the tarantula genus Aphonopelma Pocock, 1901 (Araneae, Mygalomorphae, Theraphosidae) within the United States. ZooKeys 560: 1-340. https://doi.org/10.3897/zookeys.560.6264

Hansen H.J. 1921. The Pedipalpi, Ricinulei, and Opiliones (exc. Op. Laniatores) collected by Mr. Leonardo Fea in tropical West Africa and adjacent islands. Studies on Arthropoda 1: 1-55.

Harvey M.S. 2003. Catalogue of the Smaller Arachnid Orders of the World. CSIRO Publishing, Collinwood, Victoria, Australia.

Hebert P.D., Cywinska A., Ball S.L. \& Dewaard J.R. 2003. Biological identifications through DNA barcodes. Proceedings of the Royal Society of London. Series B: Biological Sciences 270 (1512): 313321. https://doi.org/10.1098/rspb.2002.2218 
Hebert P.D., Penton E.H., Burns J.M., Janzen D.H. \& Hallwachs W. 2004. Ten species in one: DNA barcoding reveals cryptic species in the neotropical skipper butterfly Astraptes fulgerator. Proceedings of the National Academy of Sciences of the United States of America 101 (41): 14812-14817. https://doi.org/10.1073/pnas.0406166101

Kapli P., Lutteropp S., Zhang J., Kobert K., Pavlidis P., Stamatakis A. \& Flouri T. 2017. Multi-rate Poisson tree processes for single-locus species delimitation under maximum likelihood and Markov chain Monte Carlo. Bioinformatics 33 (11): 1630-1638. https://doi.org/10.1093/bioinformatics/btx025

Katoh K. \& Toh H. 2008. Recent developments in the MAFFT multiple sequence alignment program. Briefings in Bioinformatics 9 (4): 286-298. https://doi.org/10.1093/bib/bbn013

Kearse M., Moir R., Wilson A., Stones-Havas S., Cheung M., Sturrock S. \& Drummond A. 2012. Geneious Basic: an integrated and extendable desktop software platform for the organization and analysis of sequence data. Bioinformatics 28 (12): 1647-1649. https://doi.org/10.1093/bioinformatics/bts199

Luo A., Ling C., Ho S.Y. \& Zhu C.D. 2018. Comparison of methods for molecular species delimitation across a range of speciation scenarios. Systematic Biology 67 (5): 830-846.

https://doi.org/10.1093/sysbio/syy011

Monaghan M.T., Wild R., Elliot M., Fujisawa T., Balke M., Inward D.J. \& Vogler A.P. 2009. Accelerated species inventory in Madagascar using coalescent-based models of species delineation. Systematic Biology 58 (3): 298-311. https://doi.org/10.1093/sysbio/syp027

Murienne J., Benavides L.R., Prendini L., Hormiga G. \& Giribet G. 2013. Forest refugia in Western and Central Africa as 'museums' of Mesozoic biodiversity. Biology Letters 9 (1): e20120932.

https://doi.org/10.1098/rsbl.2012.0932

Naskrecki P. 2008. A new ricinuleid of the genus Ricinoides Ewing (Arachnida, Ricinulei) from Ghana. Zootaxa 1698 (1): 57-64. https://doi.org/10.11646/zootaxa.1698.1.4

Navarro-Rodríguez C.I. \& Valdez-Mondragón A. 2020. Description of a new species of Loxosceles Heineken \& Lowe (Araneae, Sicariidae) recluse spiders from Hidalgo, Mexico, under integrative taxonomy: morphological and DNA barcoding data (CO1+ ITS2). European Journal of Taxonomy 704: 1-30. https://doi.org/10.5852/ejt.2020.704

Ortiz D. \& Francke O.F. 2016. Two DNA barcodes and morphology for multi-method species delimitation in Bonnetina tarantulas (Araneae: Theraphosidae). Molecular Phylogenetics and Evolution 101: 176193. https://doi.org/10.1016/j.ympev.2016.05.003

Penney D., Marusik Y., Wheater C.P. \& Langan A.M. 2009. First Gambian Ricinulei (Arachnida: Ricinoididae): northernmost African record for the order. Zootaxa 2021 (1): 66-68.

https://doi.org/10.11646/zootaxa.2021.1.5

Pinto-da-Rocha R. \& Andrade R. 2012. A new Cryptocellus (Arachnida: Ricinulei) from Eastern Amazonia. Zoologia 29: 474-478. https://doi.org/10.1590/S1984-46702012000500012

Pittard K. \& Mitchell R.W. 1972. Comparative morphology of the life stages of Cryptocellus pelaezi (Arachnida, Ricinulei). Graduate Studies Texas Tech University 1: 1-77. Available from http://hdl.handle.net/2346/72439 [accessed 8 Oct. 2021].

Planas E. \& Ribera C. 2015. Description of six new species of Loxosceles (Araneae: Sicariidae) endemic to the Canary Islands and the utility of DNA barcoding for their fast and accurate identification. Zoological Journal of the Linnean Society 174 (1): 47-73. https://doi.org/10.1111/zoj.12226

Platnick N.I. 1980. On the phylogeny of Ricinulei. In: Gruber J. (ed.) Verhandlungen 8. Internationaler Arachnologen-Kongress abgehalten an der Universität für Bodenkultur, Wien, 7-12 Juli, 1980: 349353. H. Egermann, Vienna. 
Platnick N.I. 2002. Ricinulei. In: Adis J. (ed.) Amazonian Arachnida and Myriapoda: 381-386. Pensoft Publishers, Sofia, Moscow.

Pons J., Barraclough T.G., Gómez-Zurita J., Cardoso A., Duran D.P., Hazell S. \& Vogler A.P. 2006. Sequence-based species delimitation for the DNA taxonomy of undescribed insects. Systematic Biology 55 (4): 595-609. https://doi.org/10.1080/10635150600852011

Posada D. \& Buckley T.R. 2004. Model selection and model averaging in phylogenetics: advantages of Akaike information criterion and Bayesian approaches over likelihood ratio tests. Systematic Biology 53 (5): 793-808. https://doi.org/10.1080/10635150490522304

Puillandre N., Lambert A., Brouillet S. \& Achaz G. 2012. ABGD, Automatic Barcode Gap Discovery for primary species delimitation. Molecular Ecology 21 (8): 1864-1877.

https://doi.org/10.1111/j.1365-294x.2011.05239.x

Puillandre N., Brouillet S. \& Achaz G. 2020. ASAP: assemble species by automatic partitioning. Molecular Ecology 21: 609-620. https://doi.org/10.1111/1755-0998.13281

QGIS.org. 2021. QGIS Geographic Information System. QGIS Association. Available from http://www.qgis.org [accessed 8 Oct. 2021].

Rambaut A. \& Drummond A.J. 2014. TRACER, MCMC Trace Analysis Tool Version 1.6. University of Edinburgh /University of Auckland, Edinburgh/Auckland.

Rannala B. \& Yang Z. 2020. Species delimitation. In: Scornavacca C., Delsuc F. \& Galtier N. (eds) Phylogenetics in the Genomic Era: 5.5:1-5.5:18. No commercial publisher. Available from https://hal.inria.fr/PGE/hal-02536468 [accessed 8 Oct. 2021].

Selden P.A. 1992. Revision of the fossil ricinuleids. Transactions of the Royal Society of Edinburgh: Earth Sciences 83 (4): 595-634. https://doi.org/10.1017/S0263593300003333

Tahami M.S., Zamani A., Sadeghi S. \& Ribera C. 2017. A new species of Loxosceles Heineken \& Lowe, 1832 (Araneae: Sicariidae) from Iranian caves. Zootaxa 4318 (2): 377-387.

https://doi.org/10.11646/zootaxa.4318.2.10

Talavera G., Dincă V. \& Vila R. 2013. Factors affecting species delimitations with the GMYC model: insights from a butterfly survey. Methods in Ecology and Evolution 4 (12): 1101-1110.

https://doi.org/10.1111/2041-210X.12107

Tamura K., Dudley J., Nei M. \& Kumar S. 2007. MEGA4: molecular evolutionary genetics analysis (MEGA) software version 4.0. Molecular Biology and Evolution 24 (8): 1596-1599.

https://oi.org/10.1093/molbev/msm092

Teruel R. \& Armas L.F. 2008. Nuevo Pseudocellus Platnick 1980 de Cuba oriental y nuevos registros de Pseudocellus paradoxus (Cooke 1972) (Ricinulei: Ricinoididae). Boletín de la Sociedad Entomológica Aragonesa 43: 29-33.

Thorell T. 1892. On an apparently new arachnid belonging to the family Cryptostemmoidae, Westw. Kungliga Svenska Vetenskaps-akademiens Handlingar 17: 1-18.

Tourinho A.L. \& Saturnino R. 2010. On the Cryptocellus peckorum and Cryptocellus adisi groups, and description of a new species of Cryptocellus from Brazil (Arachnida: Ricinulei). Journal of Arachnology 38: 425-432. Available from http://www.jstor.org/stable/20798575 [accessed 8 Oct. 201].

Tuxen S.L. 1974. The African genus Ricinoides (Arachnida, Ricinulei). Journal of Arachnology 1: 85106. Available from https://www.jstor.org/stable/3705258 [accessed 8 Oct. 2021]. 
Valdez-Mondragón A. 2020. COI mtDNA barcoding and morphology for species delimitation in the spider genus Ixchela Huber (Araneae: Pholcidae), with the description of two new species from Mexico. Zootaxa 4747 (1): 54-76. https://doi.org/10.11646/zootaxa.4747.1.2

Valdez-Mondragón A. \& Francke O.F. 2011. Four new species of the genus Pseudocellus (Arachnida: Ricinulei: Ricinoididae) from Mexico. Journal of Arachnology 39 (3): 365-377. https://doi.org/10.1636/Ha11-02.1

Valdez-Mondragón A. \& Francke O.F. 2013. Two new species of ricinuleids of the genus Pseudocellus (Arachnida: Ricinulei: Ricinoididae) from southern Mexico. Zootaxa 3635 (5): 545-556.

https://doi.org/10.11646/zootaxa.3635.5.4

Valdez-Mondragón A. \& Juárez-Sánchez A.R. 2021. A new epigean species of ricinuleid of the genus Pseudocellus (Arachnida: Ricinulei: Ricinoididae) from a tropical sub-deciduous forest in Oaxaca, Mexico. The Journal of Arachnology 48 (3): 329-338. https://doi.org/10.1636/JoA-S-20-014

Valdez-Mondragón A., Francke O.F. \& Botero-Trujillo R. 2018. New morphological data for the order Ricinulei with the description of two new species of Pseudocellus (Arachnida: Ricinulei: Ricinoididae) from Mexico. Journal of Arachnology 46: 114-132. https://doi.org/10.1636/JoA-S-17-054R1.1

Valdez-Mondragón A., Navarro-Rodríguez C.I., Solís-Catalán K.P., Cortez-Roldán M.R. \& JuárezSánchez A.R. 2019. Under an integrative taxonomic approach: the description of a new species of the genus Loxosceles (Araneae, Sicariidae) from Mexico City. ZooKeys 892: 93-133.

https://doi.org/10.3897/zookeys.892.39558

Valdez-Mondragón A., Cortez-Roldán M.R. \& Campuzano-Granados E.F. 2020. On the Mexican ricinuleids: a new species of the genus Pseudocellus (Arachnida: Ricinulei: Ricinoididae) from the cloud forest of Chiapas, Mexico. Revista Mexicana de Biodiversidad 91: 1-12.

https://doi.org/10.22201/ib.20078706e.2020.91.3224

Wunderlich J. 2012. Description of the first fossil Ricinulei in amber from Burma (Myanmar), the first report of this arachnid order from the Mesozoic and from Asia, with notes on the related extinct order Trigonotarbida. In: Wunderlich J. (ed.) Fifteen papers on extant and fossil spiders (Araneae). Beiträge zur Araneologie 7: 233-244.

Wunderlich J. 2015. New and rare fossil Arachnida in Cretaceous Burmese amber (Amblypygi, Ricinulei and Uropygi: Thelephonida). In: Wunderlich J. (ed.) Mesozoic spiders and other fossil Arachnids. Beiträge zur Araneologie 9: 409-436.

Wunderlich J. 2017. New extinct taxa of the arachnid order Ricinulei, based on new fossils preserved in Mid Cretaceous Burmese amber. In: Wunderlich J. (ed.) Ten papers on fossil and extant spiders (Araneae). Beiträge zur Araneologie 10: 48-71.

Zhang J., Kapli P., Pavlidis P. \& Stamatakis A. 2013. A general species delimitation method with applications to phylogenetic placements. Bioinformatics 29 (22): 2869-2876.

https://doi.org/10.1093/bioinformatics/btt499

Manuscript received: 28 June 2021

Manuscript accepted: 17 September 2021

Published on: 29 October 2021

Topic editor: Tony Robillard

Section editor: Rudy Jocqué

Desk editor: Pepe Fernández 
Printed versions of all papers are also deposited in the libraries of the institutes that are members of the EJT consortium: Muséum national d'histoire naturelle, Paris, France; Meise Botanic Garden, Belgium; Royal Museum for Central Africa, Tervuren, Belgium; Royal Belgian Institute of Natural Sciences, Brussels, Belgium; Natural History Museum of Denmark, Copenhagen, Denmark; Naturalis Biodiversity Center, Leiden, the Netherlands; Museo Nacional de Ciencias Naturales-CSIC, Madrid, Spain; Real Jardín Botánico de Madrid CSIC, Spain; Zoological Research Museum Alexander Koenig, Bonn, Germany; National Museum, Prague, Czech Republic. 